\title{
PREGNANCY OF THE WIFE OF A COMPLETE PARAPLEGIC BY HOMOLOGEOUS INSEMINATION AFTER AN INTRATHECAL INJECTION OF NEOSTIGMINE
}

\author{
By P. A. Chapelle, M. Jondet, J. Durand and A. Grossiord \\ Raymond Poincaré Hospital, Garches, Paris
}

Abstract. A case of successful pregnancy following artificial insemination following intrathecal neostigmine injection in the wife of a complete traumatic paraplegic $\left(\mathrm{T}_{7}-\mathrm{T} 8\right.$ to TII-TI2) is described.

Key word: Artificial insemination.

MORE than 5 years ago, whilst in Professor Grossiord's service of neurological re-education at the Raymond Poincaré Hospital in Garches, we started a genitosexual clinic.

If at first our therapeutic possibilities were poor, they are now greatly improved by the experience brought to us by approximately 400 consultations and tests exclusively devoted on genito-sexual problems.

An ejaculation may be induced by intraspinal injection of neostigmine in paraplegics (Guttmann, 1949). This technique has been frequently used and is well known. A synopsis was made by Guttmann and Walsh (I97I), however to our knowledge only one publication exists relating a pregnancy brought to term. (Spira, I958.)

After a brief description of the conditions needed for an ejaculation in a paraplegic case, we shall relate the observation of $\mathrm{Mr}$ and $\mathrm{Mrs} \mathrm{B}$ for whom we were able to obtain a pregnancy by insemination on Mrs B with Professor Netter's assistance after inducing an ejaculation with neostigmine on $\mathrm{Mr} \mathrm{B}$.

In a previous article (Chapelle et al., 1974) we described in detail the optimum conditions needed for the success of the neostigmine test.

For an ejaculation-either spontaneous or induced-in a paraplegic, at least two of the TII, TI2 or LI segments should be intact, situated outside the spinal cord syndrome and connected to the effecting organs.

This dorso-lumbar junction can be above lesional or sub-lesional. In the above lesional case ejaculation can occur. It is often spontaneous or 'dribbling'. In this case, the erection is nearly always poor (the terminal cone is destroyed) and very rarely allows satisfactory sexual intercourse. However in sub-lesional cases the ejaculation can only be reflex but it is clonic. A spontaneous ejaculation is rare, normally linked to prolonged masturbation and coinciding with somatic contractions. The first ejaculation may be unpleasant.

In both these cases, to obtain an ejaculation, we recommend to our patients: (a) First, a lengthy masturbation and provocation of inferior limb contractions if possible. (b) If this fails, we try an electrically provoked ejaculation. This technique which has given very good results on certain animal species has, so far, proved to be rather poor on humans. We think that the cause of this failure is more anatomical than technical. (c) Last, the intrathecal injection of neostigmine.

Slow injection of $0.3-0.5 \mathrm{mg}$ of neostigmine after mixing the cerebrospinal fluid is made on a patient in a specially trained hospital environment capable of coping with possible secondary effects which are very rare but which can be very

$$
\text { I } 4 / 3-A
$$


serious. On our part we now only use this technique on patients whose cord lesion is situated below $\mathrm{T}_{3}$.

After an hour, we ask the patient to masturbate and we collect the sperm in a specially conceived, disposable, sterile container.

It is this technique which we used on couple B and is described below.

\section{Technique}

$\mathrm{Mr}$ Bou, born in 1948 , became a paraplegic following a 9 metre fall in 1967. His spinal cord syndrome extends from T7-T8 to TII-TI2. His sexual activity is psychologically satisfying for the couple.

In Febuary I974 a testicular biopsy was performed but an orchitis followed. The histology reveals a testis nearly normal. The seminal ducts were of a normal size and contained all the elements of the seminal line up to the stage of spermatozoa. The duct walls did not show any marked abnormality and the interstitial gland was nearly normal.

In May I974 a first intrathecal injection of prostigmine (PIR) was tried at Garches and $4 \mathrm{ml}$ of spermatic fluid presenting 4I 000 spermatozoa per $\mathrm{ml}$, 60 per cent of which were motile, were collected.

In May 1975, following a treatment by Arginin, corticoids and antibiotics, a second intrathecal injection was performed at Necker Hospital with $0.25 \mathrm{mg}$ of prostigmine. Forty-five minutes later, the first ejaculation induced by masturbation was obtained followed by three others. All four occurred within a 2-hour period.

Table I presents the results of the first two ejaculations, the last two showing a diminution in number and mobility by comparison to the second one.

TABLE I

\begin{tabular}{lll}
\hline & First ejaculation & Second ejaculation \\
\hline Volume $(\mathrm{ml})$ & 6 & 3 \\
Number by $\mathrm{mm}^{3}$ & $\mathrm{130} 000$ & $\mathrm{I00} 000$ \\
Percentage in mobility & $30 \%$ & $5 \%$ \\
Motility & 4 & 2 \\
Morphology & $85 \%$ normal & \\
& $15 \%$ atypical \\
\hline
\end{tabular}

The first $6 \mathrm{ml}$ ejaculation, the largest, was comparable to spermograms seen in certain cases presenting very unfrequent ejaculation and it is possible to explain the large number of spermatozoa ( 780 millions in total) by their accumulation in the genital apparatus. The inert forms being therefore assimilated to the eldest ones. This is only an hypothesis which needs further verification.

On this spermogram, we found 30 per cent mobile forms with a mobility scored at 4. This last parameter gives the progression speed of the spermatozoa and it is subjectively marked between 0 and 5. We shall use instruments calculating the speed of microns in seconds as soon as these are available (David, 1975). In the present case, the motility can be considered of very good quality.

The spermoculture performed on the first ejaculation did not show traces of pathological germs. 
At last, to complete the observation, we tested the FSH, $\mathrm{LH}$ and the testosterone which showed perfectly normal plasmatical ranges.

\section{Fertilisation}

Our aim was to congeal the sperm so that it could be used later for a homologeous insemination. Unfortunately, our actual technique of congelation destroys an average of 20 per cent of the spermatozoa (Jondet et al., 1975a) and with fresh sperm containing only 30 per cent of mobile forms, the manipulation of freezing and defreezing would not have left us more than ro per cent of mobile forms which is a minimum and insufficient for our purposes.

We therefore choose the solution of insemination with fresh sperm and we convoked couple Bou on the I 5 th day of Mme Bou's menstrual cycle based on her previous menothermic temperature charts.

A gynaecological examination revealed that the cervix score (opening of the cervix uteri, quantity of glair, fluidity and crystallisation) was nearly maximum at I I (Insler et al., I970).

$\mathrm{I} \cdot 5 \mathrm{ml}$ of sperm coming from the first ejaculation were instilled in a cervical cap (Jondet et al., I975b) following a previously described technique, this amounts to around 60 million mobile spermatozoa.

On the first post-insemination day, we noticed (i) a latent thermal period with a morning temperature of $37^{\circ} \mathrm{C}$, (ii) a noticeable regression of the cervix score, (iii) a strongly positive Huhner test (Jondet, 1975) with, after magnification by 250 , a number of strongly mobile spermatozoa superior to 20 , and (iv) after questioning the patient, a pelvic pain on the evening of insemination, which we can consider as ovulatory.

All necessary requirements for fertilisation were, therefore, united (Millet, 1974) but we all know the numerous problems of homologeous inseminations and their risks. Nevertheless, 30 days later, we had the confirmation of a pregnancy. On February 23 1976, Geraldine, weighing 4250 kilos and perfectly constituted, was born.

The blood groups were $\mathrm{B} \mathrm{Rh}^{+}$for $\mathrm{Mr} \mathrm{B}, \mathrm{AI} \mathrm{Rh}^{+}$for $\mathrm{Mrs} \mathrm{B}$ and ${\mathrm{O} \mathrm{Rh}^{-}}^{-}$ for baby Geraldine. Baby Geraldine's blood group, different from her parents' blood group, could evidently inspire some reservation.

So we asked for a geneticist's advice, and we were told that a $\mathrm{B} \mathrm{Rh}^{+}$man and a $\mathrm{AI} \mathrm{Rh}^{+}$woman can have a $\mathrm{O} \mathrm{Rh}^{-}$child.

On the other hand, and above all, the insemination technique used (the cervix cap is left on the cervix uteri during 24 hours long, during the fecundation period) strictly forbids any foreign spermatic intake during the fecundation period.

\section{Discussion}

The above observations demonstrate that a 28 -year-old man, completely paraplegic for 7 years, and having suffered an iatrogenic orchitis can still have a spermatogenesis perfectly compatible with fertilisation. Also that, when the thoracic-lumbar junction is partially spared by the lesional syndrome, one can fairly give a reasonably favourable prognosis (Chapelle et al., 1974). The most delicate problem remains in the accuracy of the neurological examination of this special zone, which can be particularly poor on a semeiotic plan.

Modern artificial insemination techniques should increase in the years to come. These successes should no longer be exceptional. It is obvious that a 
good coordination and strong team spirit between the different services involved (neurology, gynaecology) will be the most important guarantees for our future chances.

\section{SUMMARY}

The authors report an observation of pregnancy brought to term on the wife of a complete paraplegic.

Mr B has been paraplegic for 7 years following a severe fall. His cord syndrome extends from $\mathrm{T}_{7}-\mathrm{T} 8$ to $\mathrm{TII}_{\mathrm{I}}-\mathrm{T}_{\mathbf{2} 2}$. The ejaculation was therefore possible. His testicular biopsy was sub-normal and the spermatic fluid of normal quality.

The first artificial insemination on his wife has been brought to a successful conclusion.

\section{RÉSUMÉ}

Les auteurs relatent l'observation d'une grossesse menée à terme chez la femme d'un paraplégique complet.

Le père est paraplégique depuis 7 ans après une chute de 9 mètres. Son syndrome lésionnel s'étend de T7-T8 à TI I-Ti2. L'éjaculation est donc possible.

Sa biopsie testiculaire est sub-normale. Le sperme de qualité moyenne.

La première insémination artificielle de son épouse est suivie de succés.

\section{ZUSAMMUNGFASSUNG}

Die Verfasser berichten über eine zum Abschluss gebrachte Schwangerschaft bei der Ehefrau eines völlig Quergelähmten.

Herr B ist seit sieben Jahren völlig querschnittgelähmt nach einem Sturz aus neun Meter Höhe. Sein Läsionssyndrom erstreckt sich von T7-T8 bis TI I-TI2, schliesst jedoch den Samenerguss nicht aus.

Das Ergebnis seiner Hodenprobe ist fast normal. Der Samen ist mittlerer Qualität.

Die erste künstliche Befruchtung seiner Ehefrau war erfolgreich.

Acknowledgments. We thank in particular: Dr Fanic, the family physician of the married couple Bou, whose help allows this observation. Dr Gordeef's anatomopathology laboratory (Nantes) who kindly let us have the histologic slides of this observation. Pr. Ag. Cl. Got who kindly explained to us the histologic slides of Mr B's testis.

\section{REFERENCES}

Chapelle, P. A., Gaussel, J. J. \& Grossiord, A. (I974). Réflexions concernant les problèmes génito-sexuels des paraplégiques (à propos de 165 dossiers). Ann. de Med. Phys. I, I.

Chapelle, P. A., Piera, J. B., Pannier, S., Lacert, Ph. \& Grossiord, A. (I97I). Fonctions sexuelles et génitales chez les paraplégiques. Revue du Prat. 21, 25.

Chapelle, P. A., Piera, J. B. \& Bedoiseau, M. (I972). Pronostic et possibilités thérapeutiques des fonctions génitales de l'homme para ou tétraplégique. Gème Congrés Inter. de Méd. Phys. 2-6 Septembre 1972, Barcelona, edit. Minist. du Travail, Instituto Nacional de prevesion, Tome I, pp. 758-765.

David, G. (1975). Problèmes techniques de l'examen du sperme. Exploration de la Fonction Gonadique, Editions SEPE, Oct 75 p.R.

Guttmann, L. (I949). IV intern. Neurol. Cong. Paris (Com.), 2, 69.

Guttmann, L. \& Walsh, J. J. (I97I). Prostigmin assessment test of fertility in spinal man. Paraplegia, $\mathbf{1}, 39$. 
PARAPLEGIC'S WIFE PREGNANT BY HOMOLOGEOUS INSEMINATION I77

Insler, V., Melmed, H., Eden, E., SerR, D. \& Lunefeld, B. (I970). Comparison of Various Methods used in Monitoring Gonadotropin in Clinical Application of Human Gonadotropins, edited by G. Bettendorf and V. Insler. Thieme G., Stuttgart, 87.

Jondet, M., Millet, D., Cornuau, J., Drapier, E., Picaud, C. \& Netter, A. (I975a). Utilisation du sperme congelé pour l'insémination humaine hétérologue. Gynécologie, 6, 285.

Jondet, M., Millet, D. \& Netter, A. (1975). Adaptation d'une cape cervivale pour l'insémination artificielle humaine. F. Gyn. Obst. Biol. Repr. 4, I4I.

Jondet, M. (1975). Le test de Huhner. G. Med. de France, 8, 833.

Millet, D. (I974). L'insémination artificielle. In Actualités en Gynécologie Obstétrique, edited by Sandoz, no. I5.

SPIRA, R. (1958). Artificial insemination after intrathecal injection of neostigmine in a paraplegic. Lancet, I, 670. 